\title{
Smartphone Addiction: Critical Issues
}

\author{
Mohammad Qasim Abdullah* \\ Department of Clinical Psychology, Faculty of Education, University of Aleppo, Syria
}

Submission: October 30, 2017; Published: November 20, 2017

*Corresponding author: Mohammad Qasim Abdullah, Department of Clinical Psychology, Faculty of Education. University of Aleppo, Syrian Arab Republic, Syria, Email: mk.abdalah@yahoo.com

\section{Introduction}

One behavioral addiction that has received considerable media attention is the pathological use of certain information and communications technologies, such as the Internet, cell phones, and video games. Cell phone plays an essential role in communications throughout the world [1]. If humans learned to control their impulses related to cell phone use, they would be given the opportunity to interact and communicate with the present environment in which they are surrounded [2]. In today's world addiction is no longer restricted to alcohol or substance use. Behavioral addiction among youth is an increasing trend noted in the recent past.

Researchers define technological addictions as a subset of behavioral addictions - one that involves human -machine interaction; and which develops when people become dependent on a device to reduce negative mood states or increase positive consequences, [3]. Some people claimed that these addictive behaviors and habits arise because they don't want to be disconnected from their friends and family. They need to have their cell phones so they are able to respond, or reach out to people instantly, and impulsively. Others believe that the use of technology to communicate has decreased our ability to communicate with one another in person. As one survey participant put it, "I think people often forget how to interact face-to-face because we use technology as a crutch to avoid true interaction." [1].

\section{Critical Issues}

First issue: There are many concepts have been used to determine and conceptualizing the term of "Smartphone addiction" e.g.: "mobile mis-use", "smartphone abuse", problematicuse of mobile", maladaptive use of mobile", addictive behavior of smartphone", "nomophobia',"' Smartphone dependency". "Pathological use',' compulsive behavior", problematic use of Smartphone", " mobile Impulsive behavior"[4]. There is no uniformity in the definition of Mobile phone addiction among studies because of: a) The variety of addiction symptoms associated with Smartphone use;

b) The wide variety of new Smartphone functions; and

c) The different problematic outcomes associated with Smartphone addiction $[3,4]$.

Second Issue: Most of scales for assessing "smartphone addiction" have been noted as problematic to at least some degree for an analysis. Because of the difficulty in exactly defining addiction, some researchers have adopted less controversial descriptions of these behaviors, including "problematic mobile phone usage" and "Smartphone dependency". (Tossell, Kortum, Shepard, Rahmati, Zhong, 2015). In relation to this issue, there is no consent to the criteria for diagnosing this complex behavior [5].

Third issue: Substance addiction is explained the to types of dependence: 1- physical-biological dependence, 2- mentalpsychological dependence. The urgent critical question is that, can we use the term "addiction" on technology use and abuse? On the other hand, smartphone addiction including, just, psychological and behavioral dependence, and should be differentiated from substance and drug addiction.

Fourth issue: Self -report for assessing smartphone use is commonly used in clinical researches, and this instrument revealed the problem of "accuracy of evaluation and self-report". Dozens of problems have been expressed regarding the onset, manifestation levels, maintaining, term-levels, its consequences and effects on personality. Particularly focusing on teenagers' mobile phone usage, literature has provided evidence of them being used for both positive purposes and negative reasons.

Fifth issue: The methodological comments regarding investigation the smartphone addiction is that, the sample of participants and the generalization of the findings and results. This dilemma directs our attention to the internal validity and external validity. 
Sixth issue : using technology in general, and smartphone in special, lead us do understand the developmental period of users, and its relations to needs and developmental tasks especially in childhood and adolescence.

In sum, it can be concluded that the considerable amount of cell phone use in today's global society isn't as much an issue of addiction and dependence, but rather it is an issue of controlling impulses. Allowing teenagers to use mobile phones by setting a minimum age limit and by providing education (making the teens understand the negative impacts and the best ways to deal with them). For good understanding the Smartphone addiction, it is very significant to implement the longitudinal and experimental methodology for investigating the Smartphone addiction and its relationships with psychological and demographic variables.

\section{References}

1. Jones T (2014) Students Cell Phone Addiction and Their Opinions. The Elon Journal of Undergraduate Research in Communications 5(1): 7480.

2. Mozes Alan (2013) Can Excessive Cell phone Use Become an Addiction? US News. U.S. News \& World Report.

3. Grzywacz B (2013) Number of Cell Phones in the US. Number of Cell Phones in the US. N. p. Web 28.

4. Abdullah Q M (2017) Introduction to mental health. Amman: Dar Alfikr, Jordan.

5. Griffiths MD (2004) Does Internet and computer "addiction" exist? Some case study evidence. Cyberpsychol Behavior 3 (2): 211-218.

\section{Your next submission with Juniper Publishers}

\section{will reach you the below assets}

- Quality Editorial service

- Swift Peer Review

- Reprints availability

- E-prints Service

- Manuscript Podcast for convenient understanding

- Global attainment for your research

- Manuscript accessibility in different formats

( Pdf, E-pub, Full Text, Audio)

- Unceasing customer service

Track the below URL for one-step submission https://juniperpublishers.com/online-submission.php 